\title{
Adolescent suicide: an individual disaster, but a systemic failure
}

\author{
Marialuisa Cavelti ${ }^{1} \cdot$ Michael Kaess $^{1,2}$
}

Published online: 1 July 2021

(c) The Author(s) 2021

Suicide is among the leading causes of death worldwide, especially among adolescents $[8,24]$. The estimated suicide rate for 10- to 19-year-olds based on WHO mortality data from 2010 to 2016 is $3.77 / 100,000$ people [12]. Estimated lifetime prevalence of suicide ideation, plans, and attempts among adolescents are $12.1 \%, 4.0 \%$, and $4.1 \%$, respectively [20]. The risk of suicide is relatively low in childhood, and significantly increases from early adolescence to late adolescence and early adulthood [7, 12]. The high prevalence and significance of adolescent suicidal behavior stand in strong contrast to the fact that "at-risk youths" are notoriously poor help-seekers [30]. For example, a recent study in adolescents between 11 and 19 years of age found a delay of approximately one year between the first suicide attempt and receiving appropriate professional care [19].

Since adolescence represents a critical time window of opportunity for early detection, prevention and intervention of suicidal behavior, great efforts have recently been made to identify risk and protective factors for suicidal behavior in adolescence $[2,7,29]$. The knowledge of risk and protective factors paves the way for new efforts to identify those adolescents who are at risk for suicide, and for indicated intervention targeting this group, along with population-based universal suicide prevention strategies. In this editorial, we highlight interpersonal risk and protective factors for suicidal behavior in adolescents, and call for a more systemic approach in prevention and treatment programs.

In this issue of European Child and Adolescent Psychiatry, Grande and colleagues [13] reported a range of family characteristics associated with the occurrence of adolescent suicide. Indeed, living in an atypical family constellation $[13,28]$, parental separation or divorce, unemployment or

Michael Kaess

michael.kaess@upd.ch

1 University Hospital of Child and Adolescent Psychiatry and Psychotherapy, University of Bern, Bern, Switzerland

2 Department of Child and Adolescent Psychiatry, Centre for Psychosocial Medicine, University Hospital Heidelberg, Heidelberg, Germany low income [23]), parental or family history of mental illness [25] or parent loss due to suicide or death due to another cause $[5,6]$ range among the most common familial risk factors for adolescent suicide and suicidal behavior. In addition, interpersonal risk factors, such as the quality of relationships to parents, peers, and teachers, seem to play an important role in the etiology of suicidal behavior in adolescents. For example, early maltreatment (e.g., emotional or physical neglect and emotional, physical, or sexual abuse) is a wellestablished risk factor for suicidal behavior in adolescents (for systematic reviews and meta-analyses, see [1, 27, 35]. The timing of maltreatment seems to matter, with earlier exposure having an even more devastating impact on the young person compared to later exposure [1,9]. This finding may be partly explained by the fact that the risk for suicidal behavior is higher when the abuser is a member of the immediate or extended family compared to a non-related person [3]. Maltreatment does not necessarily have to happen within family relationships, but the likelihood of that happening seems to be higher the younger the child is. Besides maltreatment, other aspects of family relationships have also been linked to suicide risk in youth, such as negative family climate, family conflict, or maladaptive parenting (e.g., low parental monitoring or inconsistent discipline) $[18,27]$. In contrast, parental support, family cohesion, and a consistent discipline by parents have been identified as protective factors for suicidal behavior in adolescents [17, 26, 32].

While at the beginning of life relationship experiences primarily occur within familial interactions, it is one of the developmental tasks of adolescents to gradually take a step back from the family and to increasingly build up peer and other social relationships. Accordingly, it may be little surprising that there is evidence for bullying victimization, a lack of close friends or low peer network integration and cohesion being risk factors for suicidal behavior in youth $[4,16,17,31,34]$. At the same time, evidence also suggests that social and school connectedness or support by peers and teachers can mitigate the suicidal risk in teens [10, 15]. Taken together, with the transition from childhood to 
adolescence, peers and the school context become a source of both, risk and support.

In sum, interpersonal risk factors range among the most important and robust for adolescent suicide and suicidal behavior. Thus, it seems justified to regard suicide as a systemic failure, meaning that the sum of an adolescent's interpersonal relationships did finally not meet the individual's needs, which may of course be additionally increased by individual vulnerability and risk factors (e.g., psychiatric disorders, substance misuse or personality traits such as impulsivity).

The knowledge of potential risk factors for suicidal behavior in adolescents enables early identification, but identification alone is not effective in reducing suicidal risk; it needs to be followed by treatment addressing both the identified individual and systemic risk factors. Recent systematic reviews and meta-analyses provide evidence that there are a few effective treatments reducing suicidal behavior in adolescents [11, 14, 22]. Effective interventions have in common that they combine an individual skills training (e.g., emotion regulation, distress tolerance, mindfulness, interpersonal effectiveness, problem-solving) with an active family therapy or parent training component (e.g., parent/ family psychoeducation, emotion regulation skills, communication skills, problem-solving skills). This finding may not seem surprising if we consider the above-summarized risk and protective factors within family relationships for adolescent suicidal behavior. Thus, effective treatments may have the power to reverse familial risk mechanisms as well as to improve the quality of the parent-child relationship, and consequently act as a buffer against the negative impact of interpersonal life stressors on the suicidal risk in young people. In addition, school-based prevention, which has shown to be an effective method of suicide prevention (e.g., [33]), may set a stronger focus on school climate and peer relationships. As an example, reduction of bullying via so-called whole school approaches (e.g., [21]) may also reduce suicide risk in adolescents.

In conclusion, research on adolescent suicide over the last decades has revealed that relationship within families and the wider social context (e.g., relationships with peers or teachers) can represent both a source of risk as well as a source of protection and support that fosters resilience. Thus, future universal prevention may set a stronger focus on improving interpersonal relationships (e.g., by improving parenting competencies or by bullying prevention). Additionally, indicated interventions for adolescents with a history of suicidal behavior that target socially driven processes (e.g., family or social support) along with individual (cognitive-behavioral and self-regulatory) processes seem to be most effective in diminishing the suicidal risk in adolescents. The global health problem of adolescent suicide means not only an individual disaster, but also a systemic failure. If we are genuinely interested in providing better support for our youth at suicidal risk, a more systemic approach to risk assessment and suicide intervention and prevention is warranted.

Funding Open Access funding enabled and organized by Projekt DEAL.

\section{Declarations}

Conflict of interest None.

Open Access This article is licensed under a Creative Commons Attribution 4.0 International License, which permits use, sharing, adaptation, distribution and reproduction in any medium or format, as long as you give appropriate credit to the original author(s) and the source, provide a link to the Creative Commons licence, and indicate if changes were made. The images or other third party material in this article are included in the article's Creative Commons licence, unless indicated otherwise in a credit line to the material. If material is not included in the article's Creative Commons licence and your intended use is not permitted by statutory regulation or exceeds the permitted use, you will need to obtain permission directly from the copyright holder. To view a copy of this licence, visit http://creativecommons.org/licenses/by/4.0/.

\section{References}

1. Angelakis I, Austin JL, Gooding P (2020) Association of childhood maltreatment with suicide behaviors among young people: a systematic review and meta-analysis. JAMA Netw Open 3(8):e2012563. https://doi.org/10.1001/jamanetworkopen.2020. 12563

2. Ati NAL, Paraswati MD, Windarwati HD (2021) What are the risk factors and protective factors of suicidal behavior in adolescents? A systematic review. J Child Adolesc Psychiatr Nurs 34(1):7-18. https://doi.org/10.1111/jcap.12295

3. Brezo J, Paris J, Vitaro F, Hébert M, Tremblay RE, Turecki G (2008) Predicting suicide attempts in young adults with histories of childhood abuse. Br J Psychiatry 193(2):134-139. https://doi. org/10.1192/bjp.bp.107.037994

4. BrunsteinKlomek A, Barzilay S, Apter A, Carli V, Hoven CW, Sarchiapone M, Hadlaczky G, Balazs J, Kereszteny A, Brunner R, Kaess M, Bobes J, Saiz PA, Cosman D, Haring C, Banzer R, McMahon E, Keeley H, Kahn J-P et al (2019) Bi-directional longitudinal associations between different types of bullying victimization, suicide ideation/attempts, and depression among a large sample of European adolescents. J Child Psychol Psychiatry 60(2):209-215. https://doi.org/10.1111/jcpp.12951

5. Burrell LV, Mehlum L, Qin P (2021) Parental death by external causes and risk of hospital-treated deliberate self-harm in bereaved offspring. Eur Child Adolesc Psychiatry 30(4):539-548. https://doi.org/10.1007/s00787-020-01534-3

6. Carr MJ, Mok PLH, Antonsen S, Pedersen CB, Webb RT (2020) Self-harm and violent criminality linked with parental death during childhood. Psychol Med 50(7):1224-1232. https://doi.org/10. 1017/S0033291719001193

7. Cha CB, Franz PJ, Guzmán EM, Glenn CR, Kleiman EM, Nock MK (2018) Annual research review: suicide among youth-epidemiology, (potential) etiology, and treatment. J Child Psychol Psychiatry 59(4):460-482. https://doi.org/10.1111/jcpp.12831 
8. Cunningham RM, Walton MA, Carter PM (2018) The major causes of death in children and adolescents in the United States. N Engl J Med 379(25):2468-2475. https://doi.org/10.1056/NEJMs r1804754

9. Dunn EC, McLaughlin KA, Slopen N, Rosand J, Smoller JW (2013) Developmental timing of child maltreatment and symptoms of depression and suicidal ideation in young adulthood: results from the National Longitudinal Study of Adolescent Health. Depress Anxiety 30(10):955-964. https://doi.org/10.1002/ da. 22102

10. Forster M, Grigsby TJ, Gower AL, Mehus CJ, McMorris BJ (2020) The role of social support in the association between childhood adversity and adolescent self-injury and suicide: findings from a statewide sample of high school students. J Youth Adolesc 49(6):1195-1208. https://doi.org/10.1007/s10964-020-01235-9

11. Glenn CR, Esposito EC, Porter AC, Robinson DJ (2019) Evidence base update of psychosocial treatments for self-injurious thoughts and behaviors in youth. J Clin Child Adolesc Psychol Off J Soc Clin Child Adolesc Psychol Am Psychol Assoc Division 53 48(3):357-392. https://doi.org/10.1080/15374416.2019.1591281

12. Glenn CR, Kleiman EM, Kellerman J, Pollak O, Cha CB, Esposito EC, Porter AC, Wyman PA, Boatman AE (2020) Annual research review: a meta-analytic review of worldwide suicide rates in adolescents. J Child Psychol Psychiatry 61(3):294-308. https://doi. org/10.1111/jcpp.13106

13. Grande E, Vichi M, Alicandro G, Simeoni S, Murianni L, Marchetti S, Zengarini N, Frova L, Pompili M (2020) Suicide among adolescents in Italy: a nationwide cohort study of the role of family characteristics. Eur Child Adolesc Psychiatry. https://doi.org/ 10.1007/s00787-020-01591-8

14. Iyengar U, Snowden N, Asarnow JR, Moran P, Tranah T, Ougrin D (2018) A further look at therapeutic interventions for suicide attempts and self-harm in adolescents: an updated systematic review of randomized controlled trials. Front Psych 9:583. https:// doi.org/10.3389/fpsyt.2018.00583

15. King CA, Grupp-Phelan J, Brent D, Dean JM, Webb M, Bridge JA, Spirito A, Chernick LS, Mahabee-Gittens EM, Mistry RD, Rea M, Keller A, Rogers A, Shenoi R, Cwik M, Busby DR, Casper TC, the Pediatric Emergency Care Applied Research Network (2019) Predicting 3-month risk for adolescent suicide attempts among pediatric emergency department patients. J Child Psychol Psychiatry 60(10):1055-1064. https://doi.org/10.1111/ jcpp.13087

16. Koyanagi A, Oh H, Carvalho AF, Smith L, Haro JM, Vancampfort D, Stubbs B, DeVylder JE (2019) Bullying victimization and suicide attempt among adolescents aged 12-15 years from 48 countries. J Am Acad Child Adolesc Psychiatry 58(9):907-918. e4. https://doi.org/10.1016/j.jaac.2018.10.018

17. Li L, You D, Ruan T, Xu S, Mi D, Cai T, Han L (2021) The prevalence of suicidal behaviors and their mental risk factors among young adolescents in 46 low- and middle-income countries. J Affect Disord 281:847-855. https://doi.org/10.1016/j.jad.2020. 11.050

18. Liu X, Huang Y, Liu Y (2018) Prevalence, distribution, and associated factors of suicide attempts in young adolescents: schoolbased data from 40 low-income and middle-income countries. PLoS ONE 13(12):e0207823. https://doi.org/10.1371/journal. pone. 0207823

19. Lustig S, Koenig J, Resch F, Kaess M (2021) Help-seeking duration in adolescents with suicidal behavior and non-suicidal selfinjury. J Psychiatr Res 140:60-67. https://doi.org/10.1016/j.jpsyc hires.2021.05.037

20. Nock MK, Green JG, Hwang I, McLaughlin KA, Sampson NA, Zaslavsky AM, Kessler RC (2013) Prevalence, correlates, and treatment of lifetime suicidal behavior among adolescents: results from the national comorbidity survey replication adolescent supplement. JAMA Psychiat 70(3):300. https://doi.org/10.1001/ 2013.jamapsychiatry. 55

21. Ossa FC, Jantzer V, Eppelmann L, Parzer P, Resch F, Kaess M (2020) Effects and moderators of the Olweus bullying prevention program (OBPP) in Germany. Eur Child Adolesc Psychiatry. https://doi.org/10.1007/s00787-020-01647-9

22. Ougrin D, Tranah T, Stahl D, Moran P, Asarnow JR (2015) Therapeutic interventions for suicide attempts and self-harm in adolescents: systematic review and meta-analysis. J Am Acad Child Adolesc Psychiatry 54(2):97-107.e2. https://doi.org/10.1016/j. jaac.2014.10.009

23. Page A, Morrell S, Hobbs C, Carter G, Dudley M, Duflou J, Taylor $\mathrm{R}$ (2014) Suicide in young adults: psychiatric and socio-economic factors from a case-control study. BMC Psychiatry 14:68. https:// doi.org/10.1186/1471-244X-14-68

24. Patton GC, Coffey C, Sawyer SM, Viner RM, Haller DM, Bose K, Vos T, Ferguson J, Mathers CD (2009) Global patterns of mortality in young people: a systematic analysis of population health data. Lancet 374(9693):881-892. https://doi.org/10.1016/S01406736(09)60741-8

25. Qin P, Agerbo E, Mortensen PB (2002) Suicide risk in relation to family history of completed suicide and psychiatric disorders: a nested case-control study based on longitudinal registers. Lancet 360(9340):1126-1130. https://doi.org/10.1016/S0140-6736(02) $11197-4$

26. Samm A, Tooding L-M, Sisask M, Kõlves K, Aasvee K, Värnik A (2010) Suicidal thoughts and depressive feelings amongst Estonian schoolchildren: effect of family relationship and family structure. Eur Child Adolesc Psychiatry 19(5):457-468. https:// doi.org/10.1007/s00787-009-0079-7

27. Serafini G, Muzio C, Piccinini G, Flouri E, Ferrigno G, Pompili M, Girardi P, Amore M (2015) Life adversities and suicidal behavior in young individuals: a systematic review. Eur Child Adolesc Psychiatry 24(12):1423-1446. https://doi.org/10.1007/ s00787-015-0760-y

28. Sourander A, Klomek AB, Niemelä S, Haavisto A, Gyllenberg D, Helenius H, Sillanmäki L, Ristkari T, Kumpulainen K, Tamminen T, Moilanen I, Piha J, Almqvist F, Gould MS (2009) Childhood predictors of completed and severe suicide attempts: findings from the Finnish 1981 birth cohort study. Arch Gen Psychiatry 66(4):398. https://doi.org/10.1001/archgenpsychiatry.2009.21

29. the STOP Consortium, Carballo JJ, Llorente C, Kehrmann L, Flamarique I, Zuddas A, Purper-Ouakil D, Hoekstra PJ, Coghill D, Schulze UME, Dittmann RW, Buitelaar JK, Castro-Fornieles J, Lievesley K, Santosh P, Arango C (2020) Psychosocial risk factors for suicidality in children and adolescents. Eur Child Adolesc Psychiatry 29(6):759-776. https://doi.org/10.1007/ s00787-018-01270-9

30. Torok M, Calear AL, Smart A, Nicolopoulos A, Wong Q (2019) Preventing adolescent suicide: a systematic review of the effectiveness and change mechanisms of suicide prevention gatekeeping training programs for teachers and parents. J Adolesc 73:100112. https://doi.org/10.1016/j.adolescence.2019.04.005

31. van Geel M, Vedder P, Tanilon J (2014) Relationship between peer victimization, cyberbullying, and suicide in children and adolescents: a meta-analysis. JAMA Pediatr 168(5):435. https://doi.org/ 10.1001/jamapediatrics.2013.4143

32. Van Meter AR, Paksarian D, Merikangas KR (2019) Social functioning and suicide risk in a community sample of adolescents. J Clin Child Adolesc Psychol 48(2):273-287. https://doi.org/10. 1080/15374416.2018.1528549

33. Wasserman D, Hoven CW, Wasserman C, Wall M, Eisenberg R, Hadlaczky G, Kelleher I, Sarchiapone M, Apter A, Balazs J, Bobes J, Brunner R, Corcoran P, Cosman D, Guillemin F, Haring C, Iosue M, Kaess M, Kahn J-P, Keeley H, Musa GJ, Nemes B, Postuvan V, Saiz P, Reiter-Theil S, Varnik A, Varnik P, Carli V 
(2015) School-based suicide prevention programmes: the SEYLE cluster-randomised controlled trial. The Lancet 385(9977):15361544. https://doi.org/10.1016/S0140-6736(14)61213-7

34. Wyman PA, Pickering TA, Pisani AR, Rulison K, SchmeelkCone K, Hartley C, Gould M, Caine ED, LoMurray M, Brown CH, Valente TW (2019) Peer-adult network structure and suicide attempts in 38 high schools: implications for network-informed suicide prevention. J Child Psychol Psychiatry 60(10):1065-1075. https://doi.org/10.1111/jcpp. 13102

35. Zatti C, Rosa V, Barros A, Valdivia L, Calegaro VC, Freitas LH, Ceresér KMM, da Rocha NS, Bastos AG, Schuch FB (2017) Childhood trauma and suicide attempt: a meta-analysis of longitudinal studies from the last decade. Psychiatry Res 256:353-358. https://doi.org/10.1016/j.psychres.2017.06.082 